\title{
Knowledge, Attitude and Practices of caregivers for patients with leprosy
}

\author{
Abeer Omran Mohamed ${ }^{(1)}$ Eman Ramadan Ahmed $^{(2)}$, Manar Demien Mohamed ${ }^{(3)}$
}

1. Bsc. in Nursing, Faculty of Nursing, Minia University

2. Assistant. professor of Public Health and Preventive Medicine, Faculty of Medicine - Minia University

3. Lecturer of Community Health Nursing, Faculty of Nursing - Minia University

\section{Abstract}

Background: Leprosy is one of the oldest diseases known to humanity, it remains largely misunderstood. Misconceptions about leprosy lead to stigma towards people with the disease. In the lives of people affected by leprosy are caregivers who take on different roles in their daily upkeep. Family practices are keys for preventing illness, infection and disabilities. They support patient during Long-term treatment of leprosy. Egypt is one of the global list of twenty two high-burden countries for leprosy. Aim: The study aimed to assess knowledge, attitude and practices about leprosy among family caregivers of leprosy patients. Egypt is one of the global lists of twenty-two high-burden countries for leprosy. Study design: A cross-sectional descriptive design. Subject: A convenience sample of 165 caregivers was selected. Setting: This study was carried out at the Western Dermatology and leprosy clinic at Minia City. Tools: A structured interview questionnaire was used to assess caregivers' knowledge, attitude and practices regarding leprosy, in addition to sociodemographic characters of the participants. Results: The results showed that $84 \%$ of caregivers had poor knowledge about leprosy, $77 \%$ had negative attitude and $87.9 \%$ of them had poor practices. Educated participants had higher mean knowledge score $(2.58 \pm 1.35)$ and lower negative attitude level $(20.09 \pm 6.01)$ than non-educated $(2.35 \pm 0.98)$, and $(21.24 \pm 5.13)$, respectively, however marital status and duration of caregiving were statistically significant factors related to the level of practice. Conclusion: This study has revealed deficiencies in the knowledge, attitude and practices among the family members of patients with leprosy. Except for the education level, no statistically significant relation between family caregivers' sociodemographic characteristics and their level of knowledge or attitude about leprosy. Married caregivers and those who caring for patients more than 20 years had higher practice scores. Recommendation: Applying health education programs about leprosy for family caregivers of patients with leprosy as continued health education and behavior change activities are still the only tool to increase awareness regarding leprosy to get rid of misconception and stigma related to leprosy at community level, also design and disseminate related booklets and brochures to raise caregivers and public awareness regarding leprosy.

\section{Keywords: Knowledge, Attitude, Practice, Family caregiver, Leprosy}

\section{Introduction}

Leprosy is a chronic infectious disease that is associated with serious morbidity and is a disease of public health concern because of the case load and the social stigma attached to the disease (Poudel et al, 2019). The advance in multidrug therapy in the past 50 years has prompted a drastic decrease in the prevalence of leprosy (Leturiondo et al, 2019). However, 105 endemic countries, specifically located in Southeast Asia, in the Americas, Africa, Eastern Pacific and Western Mediterranean, still concentrate a large number of cases. There were over 210,000 new patients diagnosed in the world each year, leprosy is still a public health problem in many low and middle-income countries (WHO., 2017).

Late detection of leprosy is related to misdiagnosis, inadequate or incorrect knowledge about the disease as well as negative beliefs and attitude about leprosy among persons affected and their families. Several studies attributed delayed diagnosis of leprosy to the use of traditional medicine and/or low awareness of modern treatment, ignorance of leprosy, unavailability of services, and stigma associated with the disease (Singh et al., 2019).

Lives of people affected by leprosy have caregivers who take on different roles in the daily upkeep of the latter. These caregivers are among those who come into close contact with people affected by leprosy and also interact freely with the general public. Per their caregiving role, they observe at firsthand stigmatizing and discriminatory tendencies that are exhibited by the public towards persons who have been cured of leprosy (Asampong et al., 2018).

Stigmatized disease conditions as leprosy, courtesy or affiliate stigma is experienced by their family members, occurs when a person experiences stigma because of his/her close association with another person with a stigmatizing feature and they are both devalued, while individuals themselves do not have the mark, they are stigmatized because they live with, work with or have close social relations with individuals or groups that are labelled (Dako-Gyeke M., 2018). Family support is very much needed by leprosy patients, because support from the family can improve the quality of humanity, stability of personality, behavior, and ability to relate very well, the lack of family support results in patients withdrawing so that patients do not seek treatment and take good care of themselves (Santoso et al., 2019).

Community health nurse and all other members of the health team have important roles in the creation of knowledge about many things related to leprosy such as the prevention of disabilities, health promotion, diagnostic research, treatment, monitoring through instruments, self-care and family guidance, and epidemiological vigilance and control, all of which aim at offering an integral care to the patients (Lima et al., 2018).

\section{Significance of the study}

Elimination of leprosy as public health problem (defined as a registered prevalence of less than 1 case per 10 . 
000 population). However, pockets of endemicity have continued in many countries. There were 208,619 new leprosy cases registered globally each year, according to official figures from 159 countries from the six WHO Regions. It is a harsh reality that nine out of every 100 new cases diagnosed today are children. Egypt is one of the global list of twenty two high-burden countries for leprosy which accounted for 96\% of new cases (WHO, 2019).

Although Egypt has achieved the WHO goal of leprosy elimination since 1994, there are still certain foci with a prevalence rate of more than one case per 10,000 of the population. Almost $60 \%$ of new cases detected each year in Egypt originate from only six governorates, mainly located in the south of the country. The WHO country office Egypt, in collaboration with the Ministry of Health and Population's leprosy control programme, announced that the highest prevalence rates of leprosy are in Upper Egypt (WHO, Regional Office for the Eastern Mediterranean (EMRO), 2018).

The most recent report was submitted to WHO from Egypt on the registered prevalence of leprosy there were 721 registered prevalent cases each year of whom many cases with severe disabilities, and approximately $6 \%$ of new cases reported annually are children under 15 years of age (WHO, 2019). Early detection is necessary to reduce the physical and social consequences of the disease as the complications of leprosy depend on how timely in the disease process leprosy is diagnosed and treated (Van 't Noordende et al., 2019).

\section{Aim of the study}

This study therefore aimed to assess knowledge, attitude and practices of caregivers for patients with leprosy.

\section{Research questions}

1. What is the level of family caregivers' knowledge regarding leprosy?

2. What is the level of family caregivers' attitude towards patients with leprosy?

3. What is the level of family caregivers' practices for patients with leprosy?

4. Is there a relation between the caregivers' sociodemographic and their level of knowledge, attitude and practices?

\section{Methodology \\ Study design:}

A descriptive cross-sectional study was used to achieve the aim of the present study and answer the research questions.

\section{Setting:}

This study was conducted at Western Dermatology and leprosy clinic, the only Leprosy clinic in Minia City, Egypt. It provides a wide range of health care services for urban and rural populations from near and far districts in Minia Governorate.

\section{Study population and sampling technique:}

Purposive sampling technique was used. The participants were family caregivers of leprosy patients attending Western Dermatology and leprosy clinic with their care recipients. All participants who visited the clinic during the study period from February to August 2020 were recruited on the basis of the following criteria:
Inclusion Criteria:

- Family caregiver aged 18 years or more.

- Caregivers of people affected by leprosy who were undergoing treatment for leprosy reactions, ulcers, disability-rehabilitation.

- Primary caregivers; as persons who adopting functions of care and supervision in basic and/or instrumental daily activities of the affected person.

- Giving care to patient for at least 6 months.

\section{Exclusion Criteria:}

- Those who were paid in return for caregiving service; were excluded from this study.

- Finally, a total of 165 caregivers of registered leprosy patients who were eligible for the study were included.

\section{Data collection tool:}

A structured interview questionnaire was conducted. It was designed in the light of parameters assessed in similar studies (Seshadri et al, 2014; Stephen et al, 2014; Peters et al, 2014; Adhikari et al, 2014; Tesema and Beriso, 2015; Schutten, 2018; Zewdu et al, 2018), however it was modified to suit the situation in Egypt. The questionnaire was divided into four sections covering the following topics:

\section{I- Socio-demographic data:}

Personal characteristics and socio-demographic of the family caregiver, the nature of the relationship with the patient and the duration of caregiving/year.

\section{II- The Knowledge about Leprosy:}

Knowledge was assessed via thirteen questions that covered the following items: synonyms of leprosy disease, causes, early signs \& symptoms, mode of transmission, Contagiousness, prevention, treatment (duration of treatment, curability of disease, the way to treat) signs and symptoms of leprosy reaction and Preventive treatment for household contacts.

The questions addressed the respondent's knowledge about leprosy, which is sometimes intertwined with certain beliefs. This revealed misconceptions or misunderstandings and gaps in knowledge that were present so the whole questions were open-end questions. (Several answers were possible, so we listed it and did not give suggestions on answers; just ticked the answers given by the interviewee spontaneously) to facilitate data collection.

Each question was rated zero for wrong answer and one pointl for right answer. The knowledge score was calculated by summing the scores for all questions thus the overall score ranged from (0-13). the level of knowledge for each participant was classified as good $(>70 \%=\geq 9$ points $)$, fair $(30 \%-70 \%=4-8$ points $)$ and poor $(<30 \%=<4$ points $)$ (Van't Noordende et al., 2019).

\section{III- Attitude towards patients with Leprosy:}

Perceived attitude towards persons affected by leprosy was assessed via fourteen statements with three-points Likert scale. Scores for negative attitude statements ranged from two (for agree) to zero (for disagree). The opposite of this scoring system was used for positive attitude statements. The total score was calculated by summing the scores for all statements thus the overall score ranged from (0-28). Levels 
of attitude were then classified as negative attitude $(>70 \%=>$ 19 points $)$, neutral $(30 \%-70 \%=9-19$ points $)$ and positive attitude $(<30 \%=<9$ points $)$.

\section{Practices of family caregivers for patients with} leprosy:

Practices of caregivers were assessed via sixteen questions; supporting patient during treatment, doing periodic examination 2-items and participating in patient daily care 14item). Possible responses to each question were measured by a three-point Likert scale 'never' (zero point), 'occasionally' (one point) and 'always' (two points). The total score was then calculated by summation of the responses to all the 16 questions and ranged from 0 to 32 . The participants were classified into three categories according to their total score: as $\operatorname{good}(>70 \%=\geq 23$ points $)$, fair $(30 \%-70 \%=10-22$ points $)$ and poor $(<30 \%=\leq 9$ points $)$.

\section{Content Validity and reliability:}

The content validity for the questionnaire was assessed based on expert review. Based on experts` comments and recommendations; modifications had been made such as rephrasing of some sentences rearrangements of some sentences and adding few questions. Cronbach's alpha coefficient was used to assess the internal consistency of the questionnaire and alpha coefficient was $84 \%$.

\section{Pilot Study:}

The questionnaire was pre-tested by seventeen (17) family caregivers before the actual work began in order to test the clarity of the tool and to estimate the time required to fill the sheets. Modifications were done in the study tools based on the pilot study; this sample was excluded from the total study sample.

\section{Study procedure:}

- Permission to conduct the study was obtained from the Dean of Faculty of Nursing at Minia University.
An official permission was granted from the director of Western Dermatology and leprosy hospital.

- The study duration lasted for 6 months; the study started the beginning of the beginning of February 2020 till August 2020

- A structured interview was conducted in a separated room in the clinic: The researcher met participants and they were interviewed at times that were convenient for them during waiting time for their patients to finish examination, making ulcer care or wound care and dressing, physiotherapy and taking medication from pharmacy.

- The tools were filled by the researcher by asking the Family caregivers of patients with leprosy about items of the tools after explaining the nature and purpose of the study to them and rights to withdraw at any time.

\section{Ethical consideration:}

The study protocol was approved by the Ethical Committee of Faculty of Nursing, Minia University. Informed oral consent was obtained from all participants of the study after explaining the nature and benefits of the study. Confidentiality and anonymity of the participants were strictly maintained through a code number on the questionnaire.

\section{Statistical Analysis:}

All analyses were done using SPSS, version 22. Quantitative data were presented by mean, standard deviation while qualitative data were presented by frequency distribution. Student t-test and ANOVA test were used to compare means. Pearson correlation was used to determine the association between two quantitative variables. Graphical presentation of the data was done using Microsoft Excel 2017. The probability of less than 0.05 was used as a cut off point for all significant tests and all statistical tests were 2 tailed.

\section{Results:}

Table 1: Distribution of the family caregivers according to sociodemographic data

\begin{tabular}{|l|l|}
\hline Distribution of the family caregivers & No\% \\
\hline Age & \\
$<40$ years & $112(67.9)$ \\
$40-60$ years & $40(24.2)$ \\
$>60$ years & $13(7.9)$ \\
Mean age \pm SD & $18-75(38.2 \pm 12.5)$ \\
\hline Sex & $96(58.2)$ \\
Females & $69(41.8)$ \\
Males & \\
\hline Residence & $163(98.8)$ \\
Rural & $2(1.2)$ \\
Urban & \\
\hline Education & $105(63.6)$ \\
Illiterate & $7(4.2)$ \\
Read and write & $9(5.5)$ \\
Basic & $38(23)$ \\
Secondary & $6(3.6)$ \\
University/above & \\
\hline Occupation & $90(54.5)$ \\
Not working & $68(41.2)$ \\
Free work & $7(4.3)$ \\
Work with fixed salary & $28(17)$ \\
\hline Marital status & $129(78.2)$ \\
Single & $8(4.8)$ \\
Married & \\
Divorced/widowed & \\
\hline Monthly income & \\
\hline
\end{tabular}


Minia Scientific Nursing Journal (Print - ISSN 2537-012X) (Online - ISSN 2785-9797) Vol. (9) No. (1) June 2021

\begin{tabular}{|l|l|}
\hline Distribution of the family caregivers & $\mathbf{N o} \%$ \\
\hline Less than 1000 Egyptian pounds & $114(69.1)$ \\
$1000-2000$ & $48(26.7)$ \\
More than 2000 & $7(4.2)$ \\
\hline Relationship to the patient & \\
Daughter/Son & $60(36.4)$ \\
Partner (husband/wife) & $50(30.3)$ \\
Sister/Brother & $23(13.9)$ \\
Others & $20(12.1)$ \\
Parent (mother/father) & $12(7.3)$ \\
\hline Duration of caregiving & \\
$<10$ years & $127(77)$ \\
$10-20$ years & $29(17.5)$ \\
$>20$ years & $9(5.5)$ \\
Mean duration of caregiving \pm SD & 6 month-35 years $(8.3 \pm 7.4)$ \\
\hline Other family member suffers from leprosy & \\
No & $89(53.9)$ \\
Yes & $76(46.1)$ \\
\hline
\end{tabular}

The characteristics of the participants were shown in Table 1. More than half of the caregivers were females (58.5\%), married (78.2\%), and illiterates (63.6\%). The mean age of caregivers was $38.2 \pm 12.5$ years and only $4.3 \%$ of them had a job with fixed salary. About one-third of the participants consist of daughter/son and partners of the patient, $36.4 \%$ and $30.3 \%$, respectively. The duration of caregiving ranged from 6 months to 35 years with a mean of $8.3 \pm 7.4$ years. About $69 \%$ of the caregivers had monthly income less than 1000 Egyptian pounds. and $46.1 \%$ had other members of the family suffering from the same disease.

Table 2: Distribution of the studied family caregivers Knowledge regarding leprosy

\begin{tabular}{|c|c|c|}
\hline Family caregivers Knowledge regarding leprosy & Number $(\%)$ & $\begin{array}{c}\text { Number }(\%) \text { of } \\
\text { correct answer only }\end{array}$ \\
\hline $\begin{array}{l}\text { Other synonyms for leprosy* } \\
\text { Don't know } \\
\text { Allergy. } \\
\text { Infectious skin disease } \\
\text { Neuritis } \\
\text { Eczema } \\
\text { Hansen's disease }\end{array}$ & $\begin{array}{l}75(45.4) \\
58(35.2) \\
18(10.9) \\
12(7.3) \\
2(1.2) \\
0(0) \\
\end{array}$ & $\begin{array}{l}18(10.9) \\
0(0)\end{array}$ \\
\hline $\begin{array}{l}\text { First signs and symptoms * } \\
\text { Wounds on the skin } \\
\text { Skin patches } \\
\text { Deformities or disability. } \\
\text { Loss of sensation } \\
\text { Don't know } \\
\text { Skin patches and Loss of sensation } \\
\text { Itchiness. }\end{array}$ & $\begin{array}{l}55(33.3) \\
44(26.7) \\
32(19.4) \\
26(15.8) \\
19(11.5) \\
18(10.9) \\
3(1.3)\end{array}$ & $18(10.9)$ \\
\hline $\begin{array}{l}\text { Causes of leprosy } \\
\text { Don't know } \\
\text { Hereditary } \\
\text { Other causes } \\
\text { Germs/bacteria }\end{array}$ & $\begin{array}{l}128(77.6) \\
26(15.8) \\
11(6.6) \\
0(0)\end{array}$ & $0(0)$ \\
\hline $\begin{array}{l}\text { Contagiousness } \\
\text { No } \\
\text { Don't know } \\
\text { Yes }\end{array}$ & $\begin{array}{l}92(55.8) \\
54(32.7) \\
19(11.5) \\
\end{array}$ & $19(11.5)$ \\
\hline $\begin{array}{l}\text { Contagiousness during and/or after treatment } \\
\text { Don't know } \\
\text { Not contagious when on treatment } \\
\text { Contagious when on treatment }\end{array}$ & $\begin{array}{l}158(95.8) \\
4(2.4) \\
3(1.8)\end{array}$ & $4(2.4)$ \\
\hline $\begin{array}{l}\text { Duration of isolation period } \\
\text { Don't know } \\
\text { Know the correct answer }\end{array}$ & $\begin{array}{l}165(100 \%) \\
0(0 \%)\end{array}$ & $0(0 \%)$ \\
\hline $\begin{array}{l}\text { Transmission of Leprosy* } \\
\text { Don't know } \\
\text { By air } \\
\text { Other mode of transmission }\end{array}$ & $\begin{array}{l}147(89) \\
7(4.3) \\
11(6.7)\end{array}$ & $7(4.3)$ \\
\hline $\begin{array}{l}\text { Curability of the disease } \\
\text { Leprosy is permanent } \\
\text { Don't know } \\
\text { Leprosy is temporary (Curable) }\end{array}$ & $\begin{array}{l}70(42.4) \\
52(31.5) \\
43(26.1)\end{array}$ & $43(26.1)$ \\
\hline $\begin{array}{l}\text { How to treat leprosy disease? } \\
\text { By medication } \\
\text { Don't know } \\
\text { Other: herbal }\end{array}$ & $\begin{array}{l}155(93.9) \\
9(5.5) \\
1(0.6)\end{array}$ & $155(93.9)$ \\
\hline $\begin{array}{l}\text { Duration of treatment } \\
\text { Long } \\
\text { Don't know } \\
\text { Short }\end{array}$ & $\begin{array}{l}117(70.9) \\
47(28.5) \\
1(0.6)\end{array}$ & $117(70.9)$ \\
\hline $\begin{array}{l}\text { Disabilities } \\
\text { Don't know } \\
\text { Disabilities can't be prevented }\end{array}$ & $\begin{array}{l}90(54.5) \\
55(33.3)\end{array}$ & \\
\hline
\end{tabular}


Minia Scientific Nursing Journal (Print - ISSN 2537-012X) (Online - ISSN 2785-9797) Vol. (9) No. (1) June 2021

\begin{tabular}{|l|l|l|}
\hline \multicolumn{1}{|c|}{ Family caregivers Knowledge regarding leprosy } & \multicolumn{1}{|c|}{ Number (\%) } & \multicolumn{1}{|c|}{$\begin{array}{c}\text { Number (\%) of } \\
\text { correct answer only }\end{array}$} \\
\hline Disabilities can be prevented & $20(12.1)$ & $20(12.1)$ \\
\hline Symptoms of leprosy reaction & $165(100)$ & \\
Don't know & $0(0)$ & $0(0)$ \\
Fever, pain and inflammation of skin patches & $164(99.4)$ & \\
\hline Preventive treatment for household contacts & $1(0.6)$ & \\
Don't know & $0(0)$ & $0(0)$ \\
No & \multicolumn{2}{|l}{} \\
Yes & $140(84.8)$ \\
\hline Level of knowledge about leprosy among caregivers & $25(15.2)$ \\
\hline Poor & $0(0)$ & \\
Fair & $2.43 \pm 1.11$ & \\
Good & \\
Total knowledge score: (Mean \pm SD) &
\end{tabular}

Unfortunately, the majority of caregivers (84.8\%) had poor level of knowledge about leprosy. Nobody (0\%) answered correctly on questions about causes of leprosy, duration of isolation period, symptoms of leprosy reaction or presence of prophylactic treatment for household contacts. Few proportions of participants gave the correct answers as regard first signs and symptoms (10.9\%), contagiousness during and/or after treatment (2.4\%), mode of transmission (4.3\%), prevention of disabilities (12.1\%). About one-quarter $(26.1 \%)$ knew that leprosy is a curable disease. The overall knowledge score was $2.43 \pm 1.11$ out of the total score of 13 (Table 2).

Table (3): Distribution of the studied family caregiver attitude towards patients with leprosy

\begin{tabular}{|l|l|l|l|}
\hline Family caregiver attitude towards patients with leprosy & $\begin{array}{l}\text { Agree } \\
\text { No (\%) }\end{array}$ & $\begin{array}{l}\text { Neutral } \\
\text { No (\%) }\end{array}$ & $\begin{array}{l}\text { Disagree } \\
\text { No (\%) }\end{array}$ \\
\hline $\begin{array}{l}\text { Does a person with leprosy have the right to prevent others from } \\
\text { knowing his illness, if possible? }\end{array}$ & $129(78.2)$ & $1(0.6)$ & $35(21.2)$ \\
\hline $\begin{array}{l}\text { Does the family of a leper have the right to prevent others from knowing } \\
\text { that someone has leprosy? }\end{array}$ & $139(84.2)$ & $5(3)$ & $21(12.7)$ \\
\hline $\begin{array}{l}\text { Having an infected person in the family causes psychological, health, } \\
\text { social and economic problems for the family. }\end{array}$ & $153(92.7)$ & $10(6.1)$ & $2(1.2)$ \\
\hline $\begin{array}{l}\text { Does having a person with leprosy in your family make you feel ashamed } \\
\text { or embarrassed? }\end{array}$ & $135(81.8)$ & $17(10.3)$ & $13(7.9)$ \\
\hline Does society view the leprosy patient as inferior (feeling fear or disgust)? & $139(84.2)$ & $18(10.9)$ & $8(4.8)$ \\
\hline $\begin{array}{l}\text { Do you feel that those around you or your relatives avoid direct contact } \\
\text { with a leprosy patient? }\end{array}$ & $130(78.8)$ & $25(15.2)$ & $10(6.1)$ \\
\hline $\begin{array}{l}\text { Do you feel that those around you or your relatives treat you with } \\
\text { caution due to the presence of a leprosy patient? }\end{array}$ & $129(78.2)$ & $26(15.8)$ & $10(6.1)$ \\
\hline $\begin{array}{l}\text { Do others refuse to visit the house because of the presence of the person } \\
\text { affected by leprosy? }\end{array}$ & $126(76.4)$ & $27(16.4)$ & $12(7.3)$ \\
\hline Leprosy patient shouldn't reside with the family. & $4(2.4)$ & $1(0.6)$ & $160(97.0)$ \\
\hline $\begin{array}{l}\text { Could someone agree to marry a person with leprosy after recovering } \\
\text { from illness? }\end{array}$ & $18(10.9)$ & $4(2.4)$ & $143(86.7)$ \\
\hline Does getting leprosy cause family problems for a married person? & $131(79.4)$ & $19(11.5)$ & $15(9.1)$ \\
\hline $\begin{array}{l}\text { Does the presence of a person with leprosy in the family lead to a } \\
\text { problem in the marriage of a relative of that person? }\end{array}$ & $133(80.6)$ & $20(12.1)$ & $12(7.3)$ \\
\hline $\begin{array}{l}\text { Is there difficulty in hiring or working with someone who has been } \\
\text { successfully treated for leprosy? }\end{array}$ & $154(93.3)$ & $9(5.5)$ & $2(1.2)$ \\
\hline Do you allow children to deal with a leprosy patient? & $162(98.2)$ & $1(0.6)$ & $2(1.2)$ \\
\hline Level of attitude about leprosy among caregivers & & \\
\hline $\begin{array}{l}\text { Negative } \\
\text { Neutral } \\
\text { Positive } \\
\text { Total attitude score: (Mean } \pm \text { SD) }\end{array}$ & $\begin{array}{l}127(77) \\
8(4.8)\end{array}$ \\
\hline
\end{tabular}

In (Table 3): Regarding the attitude of family caregivers towards leprosy, $77 \%$ of the respondents have negative attitude towards leprosy patients. The analysis revealed that $78.2 \%$ and $84.2 \%$ of the participants agreed that the leprosy patient and his family respectively had the right to conceal the condition and thought their neighborhoods and relatives treating them with caution. More than three-quarters of participants stated that those around them avoid direct contact with a leprosy patient, treat them with caution and refuse to visit the house due to the presence of a leprosy patient, $78.8 \%, 78.2 \%$ and $76.4 \%$, respectively. The majority (92.7\%) of caregivers agreed that they had psychological, health, social and economic problems in the family because of an infected person, $81.8 \%$ felt ashamed or embarrassed as having a person with leprosy in the family and $84.2 \%$ stated that society viewed leprosy patient as inferior (feeling fear or disgust). Furthermore, $80.6 \%$ of our participants thought that leprosy possibly could be a problem in the marriage of a relative for a person with leprosy and $79.4 \%$ agreed that getting leprosy cause family problems for a married person. The overall Attitude score was 21.07 \pm 5.07 out of the total score of 28 .

Table (4): Distribution of the studied family caregivers' practices for patients with leprosy

\begin{tabular}{|l|l|l|l|}
\hline \multicolumn{1}{|c|}{ Family caregivers' practices for patients with leprosy } & $\begin{array}{c}\text { Always } \\
\text { No (\%) }\end{array}$ & $\begin{array}{c}\text { Occasionally } \\
\text { No (\%) }\end{array}$ & \multicolumn{1}{c|}{$\begin{array}{c}\text { Never } \\
\text { No (\%) }\end{array}$} \\
\hline Support the patient throughout the treatment. & $162(98.2)$ & $3(1.8)$ & $0(0)$ \\
\hline Do periodic examination. & $152(92.1)$ & $12(7.3)$ & $1(0.6)$ \\
\hline Eat food cooked by or with leprosy patient. & $164(99.4)$ & $0(0)$ & $1(0.6)$ \\
\hline
\end{tabular}


Minia Scientific Nursing Journal (Print - ISSN 2537-012X) (Online - ISSN 2785-9797) Vol. (9) No. (1) June 2021

\begin{tabular}{|c|c|c|c|}
\hline Family caregivers' practices for patients with leprosy & $\begin{array}{l}\text { Always } \\
\text { No }(\%)\end{array}$ & $\begin{array}{l}\text { Occasionally } \\
\text { No }(\%)\end{array}$ & $\begin{array}{l}\text { Never } \\
\text { No }(\%)\end{array}$ \\
\hline Avoid cooking or eating a certain type of food after illness. & $4(2.4)$ & $10(6.1)$ & $151(91.5)$ \\
\hline Wash the patient's clothes separately. & $3(1.8)$ & $3(1.8)$ & 154(93.3) \\
\hline Share my personal belongings with the patient. & $119(72.1)$ & $35(21.2)$ & $11(6.7)$ \\
\hline Check the patient's hands and feet. & $8(4.8)$ & $8(4.8)$ & $149(90.3)$ \\
\hline Test the water temperature before soaking patient's hands and feet in it. & $6(3.6)$ & $9(5.5)$ & $150(90)$ \\
\hline $\begin{array}{l}\text { Ensuring that the leper is wearing thick gloves or cloth during cooking or } \\
\text { holding sharp objects. }\end{array}$ & $2(2.1)$ & $2(2.1)$ & 161(97.6) \\
\hline Choose protective shoes with soft soles for leprosy patient. & $3(1.8)$ & $1(0.6)$ & 161(97.6) \\
\hline Massage the hands and feet of the leper with oil. & $3(1.8)$ & $4(2.4)$ & $158(95.8)$ \\
\hline $\begin{array}{l}\text { Can scrape the hard skin of the patient's hands and legs and moisturize } \\
\text { the skin. }\end{array}$ & $1(0.6)$ & $3(1.8)$ & 161(97.6) \\
\hline Clean the patient's wounds and take care of it. & $4(2.4)$ & $10(6.1)$ & 151(91.5) \\
\hline Examine and clean the patient's eyes. & $4(2.4)$ & $4(2.4)$ & $157(95.2)$ \\
\hline $\begin{array}{l}\text { Help the patient in doing physical therapy exercises for the eyes, hands } \\
\text { and feet. }\end{array}$ & $\mathbf{0 ( 0 )}$ & $1(0.6)$ & 164(99.4) \\
\hline $\begin{array}{l}\text { Wear protective clothing (gloves and mask) when dealing with leprosy } \\
\text { patient. }\end{array}$ & $0(0)$ & $0(0)$ & $165(100)$ \\
\hline \multicolumn{4}{|l|}{ Level of practices among caregivers } \\
\hline $\begin{array}{l}\text { Poor } \\
\text { Fair } \\
\text { Good } \\
\text { Total practice score: }(\text { Mean } \pm \text { SD })\end{array}$ & $\begin{array}{l}145(87.9) \\
19(11.5) \\
1(0.6) \\
\mathbf{8 . 3 9} \pm \mathbf{2 . 3 1}\end{array}$ & & \\
\hline
\end{tabular}

As shown in table (4), level of practices among caregivers was poor by $78.9 \%$ of participants. particles such as wound care, trimming of the wound edge, inspection of the patient's hands and feet, ensuring that the patient wear protective cloths, examine and clean the patient's eyes and help the patient to undertake physiotherapy were never done by more than $90 \%$ of participants. The overall practice score was $\mathbf{8 . 3 9} \pm \mathbf{2 . 3 1}$ out of the total score of 32 .

Table (5): Relation between knowledge, attitude and practice and socio-demographic data of family caregivers

\begin{tabular}{|c|c|c|c|}
\hline $\begin{array}{l}\text { Socio-demographic data of family } \\
\text { caregivers }\end{array}$ & $\begin{array}{l}\text { knowledge score } \\
\text { Mean } \pm \text { SD }\end{array}$ & $\begin{array}{c}\text { Attitude score } \\
\text { Mean } \pm \text { SD }\end{array}$ & $\begin{array}{l}\text { Practice score } \\
\text { Mean } \pm \text { SD }\end{array}$ \\
\hline $\begin{array}{l}\text { Age group } \\
<40 \\
40-60 \\
60> \\
\text { P-value }\end{array}$ & $\begin{array}{l}2.40 \pm 1.1 \\
2.65 \pm 1.09 \\
2.0 \pm 1.08 \\
0.7\end{array}$ & $\begin{array}{l}22.36 \pm 5.6 \\
22.75 \pm 3 \\
22.0 \pm 3.02 \\
0.3\end{array}$ & $\begin{array}{l}8.00 \pm 1.27 \\
8.52 \pm 2.65 \\
8.69 \pm 2.76 \\
0.2\end{array}$ \\
\hline $\begin{array}{l}\text { Sex } \\
\text { Males } \\
\text { Females } \\
\text { P-value }\end{array}$ & $\begin{array}{l}2.34 \pm 1.13 \\
2.48 \pm 1.10 \\
0.4\end{array}$ & $\begin{array}{l}21.24 \pm 5.13 \\
20.94 \pm 5.04 \\
0.7\end{array}$ & $\begin{array}{l}8.15 \pm 1.58 \\
8.56 \pm 2.70 \\
0.2\end{array}$ \\
\hline $\begin{array}{l}\text { Education } \\
\text { Not educated } \\
\text { Educated } \\
\text { P-value } \\
\end{array}$ & $\begin{array}{l}2.35 \pm 0.98 \\
2.58 \pm 1.35 \\
0.007\end{array}$ & $\begin{array}{l}21.53 \pm 4.51 \\
20.09 \pm 6.01 \\
0.01\end{array}$ & $\begin{array}{l}8.51 \pm 2.22 \\
8.15 \pm 2.47 \\
0.4\end{array}$ \\
\hline $\begin{array}{l}\text { Occupation } \\
\text { Working } \\
\text { Not working } \\
\text { P-value }\end{array}$ & $\begin{array}{l}2.41 \pm 1.17 \\
2.44 \pm 1.07 \\
0.8\end{array}$ & $\begin{array}{l}21.36 \pm 4.99 \\
20.83 \pm 5.14 \\
0.5\end{array}$ & $\begin{array}{l}7.98 \pm 1.39 \\
8.73 \pm 2.81 \\
0.2\end{array}$ \\
\hline $\begin{array}{l}\text { Marital status } \\
\text { Single/Divorced/widowed } \\
\text { Married } \\
\text { P-value }\end{array}$ & $\begin{array}{l}2.38 \pm 1.12 \\
2.44 \pm 1.11 \\
0.8\end{array}$ & $\begin{array}{l}20.19 \pm 5.87 \\
21.31 \pm 4.82 \\
0.2\end{array}$ & $\begin{array}{l}8.02 \pm 1.64 \\
8.49 \pm 2.45 \\
0.03\end{array}$ \\
\hline $\begin{array}{l}\text { Monthly income } \\
<1000 \\
1000-2000 \\
>2000 \\
\text { P-value }\end{array}$ & $\begin{array}{l}2.41 \pm 1.07 \\
2.40 \pm 0.94 \\
2.78 \pm 1.92 \\
0.8\end{array}$ & $\begin{array}{l}21.64 \pm 4.84 \\
20.11 \pm 4.98 \\
18.77 \pm 6.57 \\
0.1\end{array}$ & $\begin{array}{l}8.50 \pm 2.51 \\
8.31 \pm 1.996 \\
7.66 \pm 0.70 \\
0.6\end{array}$ \\
\hline $\begin{array}{l}\text { Relationship to the patient } \\
\text { Partner } \\
\text { Daughter/Son } \\
\text { Parent } \\
\text { Sister/Brother } \\
\text { Others } \\
\text { P-value }\end{array}$ & $\begin{array}{l}2.28 \pm 1.03 \\
2.57 \pm 1.18 \\
2.58 \pm 1.37 \\
2.30 \pm 1.09 \\
2.43 \pm 1.11 \\
0.6\end{array}$ & $\begin{array}{l}21.58 \pm 3.73 \\
19.78 \pm 6.08 \\
21.00 \pm 6.39 \\
22.82 \pm 2.77 \\
21.70 \pm 5.31 \\
0.1\end{array}$ & $\begin{array}{l}8.58 \pm 2.48 \\
8.35 \pm 2.57 \\
9.91 \pm 3.17 \\
7.78 \pm 0.73 \\
7.85 \pm 0.74 \\
0.07\end{array}$ \\
\hline $\begin{array}{l}\text { Duration of caregiving } \\
<10 \text { years } \\
10-20 \text { years } \\
>20 \text { years } \\
\text { P-value }\end{array}$ & $\begin{array}{l}2.35 \pm 1.10 \\
2.72 \pm 1.16 \\
2.56 \pm 1.30 \\
0.2\end{array}$ & $\begin{array}{l}20.98 \pm 5.26 \\
21.20 \pm 4.65 \\
21.88 \pm 3.75 \\
0.8\end{array}$ & $\begin{array}{l}8.20 \pm 1.88 \\
8.68 \pm 3.30 \\
10.11 \pm 3.21 \\
0.04\end{array}$ \\
\hline
\end{tabular}

Table (5) showed that except for the education level, no statistically significant relation between family caregivers' sociodemographic characteristics and their level of knowledge or attitude about leprosy. Educated participants had higher mean knowledge score $(2.58 \pm 1.35)$ and lower negative attitude level (20.09 \pm 6.01$)$ than non-educated (2.35 \pm 0.98$)$, and (21.24 \pm 5.13$)$, 
respectively. However marital status and duration of caregiving were statistically significant factors related to the level of practice. Married caregivers and those who caring for patients more than 20 years had higher practice scores.

\section{Discussion:}

The purpose of this study was to explore caregivers' knowledge, attitude and practice about leprosy. The present study found that more than half of the caregivers were women $(58.2 \%)$. The predominance of women as caregivers corroborates the findings of previous study (Stephen et al., 2014). Contrary, (Seshadri et al., 2014) found that two-thirds of family members were males and (Van't Noordende et al., 2019) reported that most of the close contacts were males. The female predominance in our study could be explained by the tendency of women to carry out many roles, frequently including domestic work, employment, and caregiving to the family members as the females were the cornerstone in the family in Upper Egypt. Furthermore, the majority of caregivers was daughter/son (36.4\%) and partner $(30.3 \%)$. (Seshadri et al., 2014) revealed that spouse was the most caregivers among the studied family members. This reflects the family bonding and support in the rural areas of Egypt.

The present study reported that the majority of participants lived in rural areas. From the researcher's point of view, literature described leprosy as the disease of predominantly rural areas and recognized as a disease of poverty predominately affecting vulnerable and marginalized populations.

Our study revealed that the majority of caregivers $(84.8 \%)$ had poor knowledge regarding leprosy. These findings are consistent with the findings of other studies conducted in India found that the caregivers had poor knowledge regarding leprosy. (Seshadri et al., 2014, Van't Noordende et al, 2019). However, in contrast with (Stephen et al., 2014) who found that family members had an adequate average level of knowledge about leprosy. From the researcher's point of view, misconception regarding the disease, myths, religious and traditional misbeliefs in Egypt is the main causes of a high level of incorrect knowledge of caregivers.

Regarding knowledge about early signs and symptoms of leprosy, the current study revealed that only ten percent of family caregivers answered correctly that both "loss of sensation" and "skin patches" are the early signs and symptoms of the disease.

These findings are in disagreement with the study done by (Seshadri et al., 2014) which showed that common symptoms were reasonably well-known to family members and (Van't Noordende et al., 2019) reported that close contacts knew early symptoms of leprosy. Also, the present study findings were in disagreement with (Stephen et al., 2014) who stated that more than two-thirds of the family members knew that skin patches with loss of sensation were the important symptoms of leprosy.

In the current study, it was found that more than three-quarters $(77.6 \%)$ of caregivers didn't know the cause of leprosy. No one gave the correct answer "germs or bacteria". This is comparable to (Van't Noordende et al, (2019) found that three-quarter of close contacts didn't know the cause of leprosy. Also, Hereditary factors and other causes of 'unclean environment, blood born, air born, immoral' were mentioned as causes of leprosy. Similar misconceptions have been in South-west region of Cameron (Tabah et al., 2018). In Ethiopia it is believed that leprosy is linked to curse/punishment by god, heredity, bad blood, and immoral conduct (Tesema and Beriso., 2015),

Regarding mode of transmission, the current study revealed that only $4.3 \%$ of family caregivers cited correctly the mode of transmission by (air), and the majority of them didn't know the right mode of transmission. In the same line, (Van't Noordende et al., 2019) found that three percent of close contacts thought leprosy is transmitted by air and contaminated soil, insects, skin contact, and eating together were reported as a mode of transmission. Also, (Seshadri et al., 2014) showed that knowledge about the mode of spread of leprosy was poor. This is much lower than reported by (Stephen et al., 2014) who stated that more than one-third of the family member said leprosy is spread through the air.

These misconceptions about the cause and mode of transmission of leprosy could be attributed to customs and beliefs deeply rooted in the Egyptian rural community.

About $26 \%$ of our participants knew that leprosy is curable or temporary disease. This is lower than the $75 \%$ reported in Cameroon (Tabah et al., 2018), and 92.5\% reported in Ethiopia (Tesema and Beriso., 2015).

The present study found that $33.3 \%$ of participants thought that the disabilities resulting from leprosy couldn't be prevented. In contrast with a study done by (Stephen et al., 2014) which showed that the majority of family members answered that deformities were preventable and (Van't Noordende et al., 2019) cited that two-thirds of contacts said that disabilities could be prevented.

The present study showed that the majority of family caregivers (95.8\%) didn't know that the patient wasn't contagious during treatment. This result was in disagreement with the study done by (Van't Noordende et al., (2019) who found that half of the contacts stated that the patient wasn't contagious when on treatment.

Unfortunately, no one knew symptoms of leprosy reaction which is considered an emergency. The current study result is congruent with the study done by (Seshadri et al., 2014) who found that only ten percent of relatives knew leprosy reactions.

Regarding the attitude of family caregivers towards leprosy, in the current study, most of the respondents have negative attitude towards leprosy patients. The analysis revealed that more than three-quarters of the participants agreed that the leprosy patient and his family respectively had the right to conceal the condition and and thought their neighborhoods and relatives treating them with caution.

In the same line, a study conducted by (Marinho et al., 2018) about "Leprosy: meanings and experiences among adolescents with the disease and their family members" which showed that most both the family members and the patient participating opted to hide the positive diagnosis of leprosy. (Dako-Gyeke., 2018) in his study about "Courtesy stigma: a concealed consternation among caregivers of people affected by leprosy" also showed that concealment was a strategy used by some caregivers. This could be explained by the fact that leprosy is considered a stigmatized disease in our community, and patients and their families afraid of prejudice and social discrimination resulted in keeping the diagnosis of leprosy as a family "secret".

Similarly, to findings from most studies in Brasil (Marinho et al., 2018), in Ghana (Asampong et al., 2018), 
in India (Seshadri et al., 2014; Van't Noordende et al., 2019) our study showed that the majority of caregivers demonstrated a negative attitude towards leprosy. Caregivers of people with leprosy are often experienced stigmatization from surrounded people. The present study found that more than three-quarters of participants stated that those around them avoid direct contact with a leprosy patient, treat them with caution and refuse to visit the house due to the presence of a leprosy patient.

The majority of caregivers in the current study agreed that they having psychological, health, social, and economic problems in the family because of an infected person and felt ashamed or embarrassed as having a person with leprosy in their family. About $93 \%$ of caregivers cited that there was a difficulty in hiring or working with people affected with leprosy. This is in agreement with (Dako-Gyeke., 2018) who found that the caregivers experienced courtesy stigma which adversely affected their efforts at securing jobs and engaging in relationships with implications for their finances and psychosocial wellbeing. (Asampong et al., 2018) who studied the caregivers' views on stigmatization and discrimination of people affected by leprosy in Ghana and found many employers were unwilling to employ leprotic patients after cure. This could be attributed to fear of contagion. Being a contagious disease, many people are scared of being infected by leprosy and as a result, keep away from caregivers of people with leprosy.

Furthermore, $80.6 \%$ of our participants thought that leprosy possibly could be a problem in the marriage of a relative for a person with leprosy and 79.4\% agreed that getting leprosy cause family problems for a married person. The current results were in disagreement with the study done by (Seshadri et al., 2014) which stated that more than half of participants agreed that non-patients could marry into a family with a leprosy patient, and only six percent agreed to divorce from a spouse if he/she had leprosy.

Two positive attitudes were found in the present study, $97 \%$ of participants disagreed about the statement that patients with leprosy shouldn't reside with them in the same place and $98.2 \%$ of them allow their children to deal with leprosy patients. In concordance, (Seshadri et al., 2014) reported that two-thirds of Indian participants refused to have leprosy patients separated and (Stephen et al., 2014) reported that more than three-quarters of the family members said that a leprosy patient could stay with them in their homes.

Regarding the level of practices among caregivers the majority of caregivers had poor practice. The present study findings were in the same line with those found by (Stephen et al., 2014) which showed that family members' practices were not adequately favorable. Additionally, (Marinho et al., 2018) reported poor practices towards the patient with leprosy. From the researcher's point of view, experiences of stigma by caregivers could contribute to increased stress and depression especially on family members which may affect their ability to provide care.

The level of knowledge and attitude regarding leprosy was influenced by caregiver education in our study, this could be attributed to the fact that better-educated caregivers would have more resources available to manage the care situation. Furthermore, no relation was found between the attitude of caregivers and their knowledge. Contrary, (Seshadri et al., 2014) stated that there is a highly statistically significant relationship between participants' knowledge and their attitude. Also, (Van't Noordende et al., 2019) reported that more knowledge about leprosy was associated with lower levels of stigma but that 'knowledge' explained only a small proportion of the variation in stigma levels. From the researcher's point of view, high level knowledge of leprosy alone does not necessarily lead to more positive attitudes towards persons affected. While knowledge is an important factor but attitudes and beliefs about leprosy are shaped by other factors like social and cultural pressures, the influence of media and familiarity with institutional practices.

\section{Conclusion:}

This study has revealed inconsistency and deficiencies in the knowledge, attitude and practice among the family members of patients with leprosy. A significant number of participants in this study had poor knowledge of the cause, mode of transmission, symptoms, referral pattern, cure and prognosis of leprosy.

Except for the education level, no statistically significant relation between family caregivers' sociodemographic characteristics and their level of knowledge or attitude about leprosy. Educated participants had higher mean knowledge score $(2.58 \pm 1.35)$ and lower negative attitude level $(20.09 \pm 6.01)$ than non-educated $(2.35 \pm 0.98)$, and $(21.24 \pm 5.13)$, respectively. However marital status and duration of caregiving were statistically significant factors related to the level of practice. Married caregivers and those who caring for patients more than 20 years had higher practice scores.

\section{Recommendations:}

- Offered a continuous planned educational program for patients, caregivers and the community to improve their knowledge, attitude as well as the practices.

- Create and distribute related booklets and brochures to educate caregivers and the general public about leprosy.

- Leprosy should be found a place in the nursing and medical education curriculum.

- Using community volunteers and the media to spread information about the cause of leprosy, its clinical manifestations, and curability, as well as sensitization messages addressing myths and stereotypes about leprosy, the community's understanding and attitudes toward leprosy may be improved

\section{References:}

(1) Adhikari, B., Shrestha, K., Kaehler, N., Raut, S., \& Chapman, S. R. (2014). Community attitudes towards leprosy affected persons in Pokhara municipality of western Nepal. Journal of Nepal Health Research Council, 11(25),264-268.

(2) Asampong, E., Dako-Gyeke, M., \& Oduro, R. (2018). Caregivers' views on stigmatization and discrimination of people affected by leprosy in Ghana. PLoS neglected tropical diseases, 12(1), e0006219.

(3) Dako-Gyeke, M. (2018). Courtesy stigma: A concealed consternation among caregivers of people affected by leprosy. Social Science \& Medicine,196,190-196.

(4) Leturiondo, A. L., Noronha, A. B., do Nascimento, M. O. O., de Oliveira Ferreira, C., da Costa Rodrigues, F., Moraes, M. O., \& Talhari, C. (2019). Performance of serological tests PGL1 and NDO-LID in the diagnosis of leprosy in a reference Center in Brazil. BMC infectious diseases, 19(1), 1-6. 
(5) Lima, M. C. V., Barbosa, F. R., Santos, D. C. M. D., Nascimento, R. D. D., \& D'Azevedo, S. S. P. (2018). Practices for self-care in Hansen's disease: face, hands and feet. Revista gaucha de enfermagem, 39, e20180045e20180045.

(6) Marinho, F. D., Avellar, L. Z., Souza, L. G. S., Nardi, S. M. T., \& Coutinho, G. C. (2018). Leprosy: meanings and experiences among adolescents with the disease and their family members. Cadernos Brasileiros de Terapia Ocupacional, 26(4), 837-848.

(7) Peters, R. M., Dadun, W. H., Zweekhorst, M. B., Damayanti, R., \& Bunders, J. F. (2014). The cultural validation of two scales to assess social stigma in leprosy. PLoS neglected tropical diseases, 8(11).

(8) Poudel, A., Shah, A., Khatiwada, S., \& Samdurkar, A. (2019). Clinico-Pathological Correlation in the Classification of Leprosy. Journal of Universal College of Medical Sciences, 7(2), 21-24.

(9) Santoso, H., Nurdina, N., \& Nurwijayanti, N. (2019). Analysis of Factors Affecting Self Care in Kusta Patients in Daha Husada Kediri Hospital. Journal for Quality in Public Health, 3(1).

(10) Schutten, K., van Brakel, W. H., Peters, R. M. H., Waltz, M., \& Koesbardiati, T. (2018). Community perception of leprosy: baseline assessment of perceptions-knowledge, beliefs, attitudes, and behaviour in East-Java, Indonesia [PhD Thesis]. Amsterdam: Vrije Universiteit/Amsterdam.pdf:https://www.leprosyinformatio n.org/files/Schutten $\% 202018 \% 20$ Community\%20perceptio n\%20on\%20leprosy\%20in\%20Pasuruan\%20Indonesia.pdf

(11) Seshadri, D., Khaitan, B. K., Khanna, N., \& Sagar, R. (2014). The tangled web: a study of knowledge and attitude towards leprosy from a tertiary care hospital in India. Indian J Lepr, 86, 27-41.

(12) Singh, R., Singh, B., \& Mahato, S. (2019). Community knowledge, attitude, and perceived stigma of leprosy amongst community members living in Dhanusha and Parsa districts of Southern Central Nepal. PLoS neglected tropical diseases, 13(1).

(13) Stephen T, Selvaraj I and Parmeswari PJ. (2014). Assessment of Knowledge, Attitude and Practice about leprosy among patients and their families in a rural community in Tamil Nadu. Indian J

(14) Tabah EN, Nsagha DS, Bissek A-CZ-K, Njamnshi TN, Njih IN-N, Pluschke G, et al. (2018). Community knowledge, perceptions and attitudes regarding leprosy in rural Cameroon: The case of Ekondotiti and Mbonge health districts in the South-west Region. PLoS Negl Trop Dis 12(2): e0006233.

(15) Tesema, A. A., \& Beriso, M. (2015). Assessment of knowledge and attitude of community on leprosy patients in Kuyera Town, West Arsi Zone, Oromia Region Southeast Ethiopia. Hereditary Genet, 4(4), 156.

(16) Van't Noordende, A. T., Korfage, I., Lisam, S., Arif, M. A., Kumar, A., \& van Brakel, W. H. (2019). The role of perceptions and knowledge of leprosy in the elimination of leprosy: A baseline study in Fatehpur district, northern India. PLoS neglected tropical diseases, 13(4), e0007302.

(17) World Health Organization, Regional Office for the Eastern Mediterranean. (2018). Screening campaign aims to eliminate leprosy in Egypt. Available from: http://www.emro.who.int/egy/egypt-events/last-milessactivities-on-eliminating-leprosy-from-egypt.html. [Last accessed on 2021 January 24].

(18) World Health Organization. (2017). Global leprosy update, 2016: accelerating reduction of disease burden. [Internet]. [cited 2017 Nov. 09]; 92 (35): 501-19.

(19) World Health Organization. (2017). Report of the informal consultation on stopping discrimination and promotion inclusion of persons affected by Leprosy, New Delhi, 1416 Nov 2017 (No. SEA-GLP-2018.1). World Health Organization. Regional Office for South-East Asia.

(20) World Health Organization. (2019). Leprosy, Key facts. Available from: https://www.who.int/newsroom/factsheets/detail/leprosy. [Last accessed on 2021 January 24].

(21) World Health Organization. (2019.)"Weekly Epidemiological Record, 2019, vol. 94, 35/36.

(22) Zewdu, A., Muna, S., and Tesema, A., (2018). Knowledge, Belief and Attitude of the Community towards Leprosy Patients in Gindeberet Woreda, West Shewa Zone. Nursing \& Healthcare International Journal. 2. 10.23880/NHIJ16000156 . 